\title{
Cytokine Measurement
}

National Cancer Institute

\section{Source}

National Cancer Institute. Cytokine Measurement. NCI Thesaurus. Code C74804.

The determination of type and amount of cytokines in a sample. 